\title{
The Pathology of Cetacean Morbillivirus Infection and Comorbidities in Guiana Dolphins During an Unusual Mortality Event (Brazil, 20 I7-20 I 8)
}

Veterinary Pathology

2020, Vol. 57(6) 845-857

(C) The Author(s) 2020

Article reuse guidelines:

sagepub.com/journals-permissions DOI: I0.I I77/0300985820954550 journals.sagepub.com/home/vet

(8)

\author{
Kátia R. Groch' ${ }^{1}$, Josué Díaz-Delgado ${ }^{1,2}{ }^{(D}$, Elitieri B. Santos-Neto ${ }^{3}$, Joana M. P. Ikeda ${ }^{3}$, \\ Rafael R. Carvalho ${ }^{3}$, Raissa B. Oliveira ${ }^{3}$, Emi B. Guari ${ }^{3}$, Leonardo Flach ${ }^{4}$, Eva Sierra ${ }^{5}$, \\ Ana I. Godinho5 ${ }^{(D}$, Antonio Fernández ${ }^{5}$, Lara B. Keid', Rodrigo M. Soares', \\ Cristina T. Kanamura6 , Cíntia Favero', Eduardo Ferreira-Machado', Carlos Sacristán', \\ Brian F. Porter ${ }^{2}$, Tatiana L. Bisi ${ }^{3}$, Alexandre F. Azevedo ${ }^{3}$, José Lailson-Brito ${ }^{3}$, \\ and José L. Catão-Dias'
}

\begin{abstract}
Cetacean morbillivirus (CeMV; Paramyxoviridae) is the most significant pathogen of cetaceans worldwide. The novel "multi-host" Guiana dolphin (Sotalia guianensis; GD)-CeMV strain is reported in South American waters and infects Guiana dolphins and southern right whales (Eubalaena australis). This study aimed to describe the pathologic findings, GD-CeMV viral antigen distribution and detection by RT-PCR (reverse transcriptase polymerase chain reaction), and infectious comorbidities in 29 Guiana dolphins that succumbed during an unusual mass-mortality event in Rio de Janeiro state, Brazil, between November 2017 and March 2018. The main gross findings were lack of ingesta, pulmonary edema, ascites, icterus, hepatic lipidosis, multicentric lymphadenomegaly, as well as pneumonia, polyserositis, and multiorgan vasculitis caused by Halocercus brasiliensis. Microscopically, the primary lesions were bronchointerstitial pneumonia and multicentric lymphoid depletion. The severity and extent of the lesions paralleled the distribution and intensity of morbilliviral antigen. For the first time in cetaceans, morbilliviral antigen was detected in salivary gland, optic nerve, heart, diaphragm, parietal and visceral epithelium of glomeruli, vulva, and thyroid gland. Viral antigen within circulating leukocytes suggested this as a mechanism of dissemination within the host. Comorbidities included disseminated toxoplasmosis, mycosis, ciliated protozoosis, and bacterial disease including brucellosis. These results provide strong evidence for GD-CeMV as the main cause of this unusual mass-mortality event.
\end{abstract}

\section{Keywords}

cetacean morbillivirus, ciliated protozoa, Guiana dolphin, marine mammal pathology, mycosis, Sotalia guianensis, Toxoplasma gondii, Paramyxoviridae

Morbilliviruses (family Paramyxoviridae, order Mononegavirales) are responsible for severe morbidity and mortality in humans ${ }^{49}$ and other animals. ${ }^{16}$ Within the genus Morbillivirus, Cetacean morbillivirus (CeMV) affects dolphins and whales, and is subclassified into 3 well-characterized strains: porpoise morbillivirus (PMV), ${ }^{48}$ dolphin morbillivirus (DMV), ${ }^{21,70}$ and pilot whale morbillivirus (PWMV), ${ }^{67}$ and 3 recent lesser-known strains, ${ }^{65,73}$ including the novel Guiana dolphin (Sotalia guianensis; GD)-CeMV in Brazil. ${ }^{31-33}$ Phylogenetic analyses based on partial phosphoprotein gene indicate that GD-CeMV diverged early from other CeMV strains, sharing the most common ancestor a few hundred years ago, and that the virus is more closely related to Rinderpest virus and other terrestrial mammal morbilliviruses than are other CeMV strains. $^{33,38}$
CeMV has been associated with somewhat cyclic epidemics primarily in the northern hemisphere and interepizootic "endemic" presentations. ${ }^{68}$ Although the disease caused by

\footnotetext{
'University of São Paulo, São Paulo, Brazil

${ }^{2}$ Texas A\&M University, College Station, TX, USA

${ }^{3}$ Universidade do Estado do Rio de Janeiro, Rio de Janeiro, Brazil

${ }^{4}$ Instituto Boto Cinza, Mangaratiba, Rio de Janeiro, Brazil

${ }^{5}$ University of Las Palmas de Gran Canaria, Canary Islands, Spain

${ }^{6}$ Adolfo Lutz Institute, São Paulo, Brazil
}

Supplemental material for this article is available online.

Corresponding Author:

Kátia R. Groch, Laboratory of Wildlife Comparative Pathology, Department of Veterinary Pathology, University of São Paulo, 05508-270 São Paulo, Brazil. Email: katia.groch@gmail.com 
CeMV has been known for more than 3 decades, ${ }^{42}$ many aspects of the pathogenesis remain unknown. ${ }^{17,68}$ Based on distribution of histologic lesions, antigen detection, and molecular analysis, CeMV-associated disease was recently classified into 4 main presentations, that is, acute systemic, subacute systemic, chronic systemic, and chronic localized encephalitis (brain-only form of DMV infection). ${ }^{68}$

The pathology of GD-CeMV infection in Guiana dolphins has only been partially described. ${ }^{19,20,31,33}$ The aim of this study was to describe the pathologic findings, viral antigen distribution and detection by RT-PCR (reverse transcriptase polymerase chain reaction), and infectious comorbidities of an epizootic GD-CeMV infection from an UME (unusual mass-mortality event) in Brazil. ${ }^{33}$

\section{Material and Methods}

\section{Case Selection, Study Area, and Epidemiologic and Biologic Data}

At least 263 Guiana dolphins died during an UME in Brazil between November 2017 and March 2018. ${ }^{15,33}$ From this group, 90 dolphins were tested by PCR, and GD-CeMV was detected in 82 (91\%). This study focuses on 29 of these GDCeMV-positive dolphins selected on the basis of tissue availability and/or suitability for histopathologic analysis and other diagnostic laboratory techniques. The dolphins were livestranded, dead-stranded, or carcasses that were retrieved adrift in Ilha Grande $\left(23^{\circ} 4^{\prime}-23^{\circ} 13^{\prime} \mathrm{S}, 44^{\circ} 5^{\prime}-44^{\circ} 22^{\prime} \mathrm{W}\right)$ and Sepetiba Bay $\left(22^{\circ} 56^{\prime}-23^{\circ} 8^{\prime} \mathrm{S}, 43^{\circ} 41^{\prime}-44^{\circ} 10^{\prime} \mathrm{W}\right)$, Rio de Janeiro state (Brazil). Epidemiologic data (date and location of stranding) and biologic data (total body length, sex, age class, nutritional status, decomposition status) were collected (Supplemental Table S1). The animals were divided into 3 age-class categories (calf, juvenile, adult) based on total body length. ${ }^{59}$ The nutritional status of each animal was classified as good, moderate, poor, or emaciated based on the degree of atrophy of the epaxial musculature, prominence of ribs, scapula, or axial skeleton, and the amount of subcutaneous, intrathoracic, and abdominal fat. The decomposition status was classified as fresh, moderate autolysis, or advanced autolysis. ${ }^{28}$

\section{Gross and Histopathologic Postmortem Analysis}

Standard postmortem examinations were performed, ${ }^{28}$ and representative tissue samples (skin, blubber, fascia, skeletal muscle, eye, gingiva, palate, tongue, esophagus, stomach, small intestine, large intestine, liver, pancreas, spleen, lymph nodes, thymus, kidney, ureter, urinary bladder, prostate, urethra, gonads, uterus, vulva, mammary gland, trachea, lung, heart, aorta, pulmonary artery, diaphragm, adrenal gland, thyroid gland, cerebrum, cerebellum, brain stem, spinal cord) were collected and fixed in $10 \%$ neutral buffered formalin for 1 to 2 weeks. These samples were trimmed, embedded in paraffinwax, sectioned at $5 \mu \mathrm{m}$ thickness, and stained with hematoxylin and eosin for light microscopic examination. Additional histochemical techniques to better characterize microscopic alterations on selected cases included periodic acid-Schiff (for fungi and basement membranes), Grocott-Gomori's methenamine silver (for fungi), Gram/Twort (for bacteria), and Masson's trichrome (for collagen/fibrosis).

\section{Immunohistochemical Analyses}

Immunohistochemical (IHC) analyses employed the following primary antibodies: a monoclonal IgG2B (kappa light chain) antibody against the nucleoprotein antigen of canine morbillivirus (1:200 dilution; CDV-NP MAb, VMRD Inc); a polyclonal antibody to Toxoplasma gondii (1:400 dilution; VMRD Inc) that was used on formalin-fixed, paraffin-embedded lymph node and liver in cases 14 and 15; a monoclonal antibody against cytokeratins (AE1/AE3; 1:2000 dilution; Biocare Medical) for intracytoplasmic keratin; and a polyclonal antibody against the ionized calcium binding adaptor molecule (Iba) 1 (Fujifilm Wako Pure Chemical Corporation) for histiocytes. Dual IHC was performed in case 2 by means of the Envision Double Staining System protocol (K-1395, Dako), following manufacturer's instructions, and included antibodies to canine morbillivirus (canine distemper virus, $\mathrm{CDV}$ ) and AE1/AE3, as well as to CDV and Iba-1, in order to better define the CeMVpositive multinucleated cells. Positive controls included lung and lymph node from GD-CeMV-positive Guiana dolphins and adrenal gland from a $T$. gondii-positive Guiana dolphin. For negative controls, sequential sections of the positive control tissues were incubated with nonimmune homologous serum instead of primary antibody.

Briefly, $4-\mu \mathrm{m}$-thick sections were deparaffinized and rehydrated through a series of graded alcohols. Endogenous peroxidase was blocked by incubation in $0.9 \%$ hydrogen peroxide in methanol for 30 minutes. Morbilliviral antigen (MA) was retrieved by heating tissue sections in distilled water in an autoclave for 5 minutes at $118^{\circ} \mathrm{C}$. Toxoplasma gondii antigen was retrieved by heating tissue sections in citrate buffer (pH 7.0) solution for 7 minutes at $90{ }^{\circ} \mathrm{C}$. The sections were blocked with $1 \%$ normal rabbit serum in phosphate-buffered saline for 30 minutes, followed by overnight incubation at $4{ }^{\circ} \mathrm{C}$ with the primary antibody or nonimmune homologous serum (negative control). The sections were washed in phosphate-buffered saline and incubated for 30 minutes with 1:40 biotinylated rabbit anti-mouse secondary antibody (morbillivirus assay) and 1:600 rabbit anti-goat secondary antibody ( $T$. gondii assay; Dako Corp). The label used was an avidin-biotinperoxidase complex (Elite ABC kit, Vector laboratories), following manufacturer's instructions. 3-Amino-9-ethyl-carbazole (AEC, Sigma Chemical Co) was used as chromogen. Slides were pre-incubated in acetate buffer for 10 minutes and incubated for 1 minute with a filtered solution of AEC $(0.05 \mathrm{~g}$ AEC was dissolved in $10 \mathrm{~mL} \mathrm{~N}, \mathrm{~N}$-dimethylformamide, $140 \mathrm{~mL}$ acetate buffer, and $150 \mu \mathrm{L}$ hydrogen peroxide at 30\%). Sections were rinsed in tap water, counterstained with Mayer's hematoxylin, and mounted with an aqueous medium.

MA distribution analysis included organ/tissue, cell type, and relative labeling intensity and abundance. The IHC 
intensity was subjectively scored (increasing intensity) as 1,2, and 3 while MA abundance was semiquantitatively evaluated according to the following scoring system: - , none;,$+<10 \%$; ,$++ 10 \%$ to $50 \%$;,$+++ 51 \%$ to $100 \%$ immunopositive cells in 10 high-power $(400 \times)$ fields. Negative controls validated the reaction when no expression of the target antigen was visualized.

\section{RT-PCR for CeMV}

For RT-PCR analysis, total RNA was extracted from selected frozen organs using Brazol Reagent (LGC Biotecnologia Ltda), according to the manufacturer's instructions. Random primers and M-MLV Reverse Transcriptase Kit (Invitrogen, Life Technologies) were used to synthesize cDNA. Amplification was performed using primers targeting highly conserved fragments of the phosphoprotein gene, as described. ${ }^{5,31,33}$ Additionally, primers targeting the nucleoprotein gene were used in cDNA from lung samples of cases 9 and 17 to investigate the genome of GD-CeMV (Forward CDV-F: 5'-ACAGRATTGCYGAGGACYTRT- ${ }^{\prime}$ and Reverse CDV-R: 5'-CARRATAACCATGTAYGGTGC- $\left.3^{\prime}\right) .{ }^{11,27}$ PCR was performed using OneTaq DNA Polymerase (New England BioLabs) according to manufacturer's instructions, with an annealling temperature of $59^{\circ} \mathrm{C}$. PCR products of positive samples were purified by using QIAquick PCR Purification Kit (Qiagen) and directly sequenced from both ends by an ABI PRISM 3100 Genetic Analyzer using a BigDye Terminator v.3.1 cycle sequencing kit (Applied Biosystems). Sequences were aligned with known morbillivirus sequences from GenBank, and the phylogenetic analysis was performed with MEGA $7 .^{44}$

\section{PCR for Sarcocystidae Protozoa (Toxoplasma gondii)}

Frozen samples were manually homogenized, and DNA was extracted from $30 \mathrm{mg}$ samples (DNeasy Blood \& Tissue Kit, QIAGEN). Extracted DNA was tested using the nested PCR assay using primers targeting the DNA spanning the 18S-5.8S rRNA interspace region common to Sarcocystidae, as described. ${ }^{64}$ Positive control consisted of DNA from $T$. gondii RH strain. Nuclease-free water instead of DNA template was used as no template control. Amplicons were electrophoresed and stained using ethidium bromide. Positive samples with amplicon size compatible with $T$. gondii (approximately 500 $\mathrm{bp)}$ were characterized by restriction fragment length polymorphism to confirm $T$. gondii detection. ${ }^{64}$

\section{PCR for Herpesvirus and Poxvirus}

Eight fresh-frozen skin lesions from cases $1(n=1), 18(n=2)$, and $22(n=5)$ were tested for herpesvirus and poxvirus by PCR (Supplemental Table S2). After manual homogenization by sterile surgical blades, DNA was extracted (NucleoSpin Tissue extraction kit, Macherey-Nagel) according to manufacturer's instructions. Herpesviral detection followed the protocol and primers described by VanDevanter et $\mathrm{al}^{71}$ for the DNA polymerase gene and by Ehlers et $\mathrm{al}^{25}$ for the glycoprotein $\mathrm{B}$ gene with slight modifications. Two different conventional PCR protocols to partially amplify the cetaceanpoxvirus DNA polymerase gene ${ }^{8,53}$ were employed to detect poxvirus. Herpesvirus-PCR-positive controls included a commercial feline vaccine against feline herpesvirus 1 (Nobivac Feline1HCPCh, MSD) for the DNA polymerase gene and a skin sample from a herpesvirus-positive Guiana dolphin for the glycoprotein B gene. Cetaceanpoxvirus-PCR-positive "tattoo-like skin lesions" from a Guiana dolphin and an Atlantic bottlenose dolphin (Tursiops truncatus; MF458199 and KU726611, respectively) were used as positive controls for poxvirus. ${ }^{55}$ Diethylpyrocarbonate-treated water was used as no template control. Amplicons were electrophoresed and visualized (Syber Safe, Invitrogen), and positive samples were directly sequenced by the Sanger method and compared with those available in public databases using a BLAST search.

\section{PCR for Brucella}

Frozen samples were manually homogenized and DNA was extracted from $30 \mathrm{mg}$ (DNeasy Blood \& Tissue Kit, QIAGEN). Extracted DNA was tested by conventional PCR with primers targeting a $262 \mathrm{bp}$ fragment of the insertion sequence element (IS711) of the Brucella genus. ${ }^{6}$ Positive control consisted of DNA from a $B$. canis reference strain (RM6/66). Nuclease-free water instead of DNA template was used as no template control. Positive samples were directly sequenced by the Sanger method and compared with those available in public databases using a BLAST search.

\section{Routine Microbiology}

Samples from selected animals (case 1, mediastinal exudate; case 2, urine; cases 25 and 29, bronchial exudate) were submitted to an independent laboratory for microbiologic analyses including culture and surface plating on routine media, for example, Columbia blood agar, and identification of isolates via the API system, along with antibiotic sensitivity testing (disc diffusion assay). Antimicrobial susceptibility testing standards M2-A9 and M7-A7 by the Clinical and Laboratory Standards Institute were used.

\section{Results}

Age categories were as follows: calf $(n=4)$, juvenile $(n=17)$, and adult $(n=8)$. Sex distribution was as follows: male $(n=$ $13)$, female $(n=16)$. Most dolphins were in poor body condition or emaciated $(n=19)$. Regarding preservation status, dolphins were classified as fresh $(n=7)$, moderate autolysis $(n=19)$, or advanced autolysis $(n=3)$. Clinical signs observed in free-ranging ${ }^{26}$ and live-stranded dolphins included neurologic signs (swimming difficulties, circling, ataxia, incoordination), compromised buoyancy, and respiratory signs (Supplemental Video S1 from case 29). 
Table I. Most Prevalent Gross Findings in 29 Guiana Dolphins (Sotalia guianensis).

\begin{tabular}{lr}
\hline Gross finding & Af/Ev (\%) \\
\hline Absence of ingesta & $23 / 29$ (79) \\
Systemic H. brasiliensis (verminous pneumonia, & $23 / 29$ (79) \\
$\quad$ polyserositis, vasculitis) & \\
Pulmonary edema & $17 / 29(59)$ \\
Skin disease (eg. TSL, HV, TRDI) & $12 / 29(41)$ \\
Gastrointestinal hemorrhage (petechiae, ecchymoses) & $11 / 29(38)$ \\
Ascites & $11 / 29(38)$ \\
Icterus & $10 / 29(34)$ \\
Hepatic lipidosis & $9 / 29(31)$ \\
Subcutaneous hemorrhage (mandibular, subscapular) & $9 / 29(31)$ \\
Gastrointestinal parasitism ${ }^{\mathrm{a}}$ & $7 / 29(24)$ \\
Systemic congestion & $6 / 29(21)$ \\
Hydrothorax & $5 / 29(17)$ \\
Hemoperitoneum & $5 / 29(17)$ \\
Lymphadenomegaly & $5 / 29(17)$ \\
Epidural hemorrhage & $4 / 29(14)$ \\
Oropharyngeal, glossal, esophageal, and/or & $4 / 29(14)$ \\
$\quad$ gastrointestinal ulcers & \\
Interstitial nephritis, mineralization & $3 / 29$ (I0) \\
Suppurative bronchopneumonia & $3 / 29(10)$ \\
Hemoglobinuria & $3 / 29(10)$ \\
Hemothorax & $3 / 29(10)$ \\
Urinary bladder hemorrhage (petechiae, ecchymoses) & $3 / 29$ (I0) \\
\hline
\end{tabular}

Abbreviations: Af, affected animals; Ev, evaluated animals; TSL, "tattoo-skin like skin lesions"; HV, herpesvirus-like skin lesions; TRDI, thromboembolic dermatitis, panniculitis, and fasciitis with infarction.

${ }^{a}$ The vast majority of these animals had Braunina cordiformis glandular and pyloric serocatarrhal gastritis.

\section{Pathologic Investigations}

Detailed gross and microscopic findings are recorded in Supplemental Table S3. The most prevalent gross findings were (by decreasing order of frequency; Table 1): lack of ingesta (79\%); verminous pneumonia, polyserositis, and proliferative endarteritis/endophlebitis caused by Halocercus brasiliensis (79\%; Supplemental Figs. S1, S2); pulmonary edema (59\%); skin disease including "tattoo-like skin lesions" (Supplemental Fig. S3), cutaneous herpesvirus-like lesions (well delineated, circular to irregular depressed areas, and/or punctate eroded or ulcerated foci), thromboembolic dermatitis, panniculitis, and fasciitis with infarction (41\%; Supplemental Fig. S4); gastrointestinal petechiae and ecchymoses (38\%); ascites (38\%); icterus (34\%; Supplemental Fig. S5); hepatic lipidosis (31\%; Supplemental Fig. S6); subcutaneous hemorrhage (31\%); gastrointestinal parasitism, primarily Braunina cordiformis (24\%; Supplemental Fig. S7); systemic congestion (21\%); hydrothorax (17\%); hemoperitoneum (17\%); and multicentric lymphadenomegaly (17\%). Novel gross pathologic findings included bilateral symmetric pulmonary hemorrhagic necrosis and emphysema (1/29; $3 \%$; Supplemental Fig. S8), and aortic valvular dysplasia (1/29; 3\%; Supplemental Fig. S9).

A wide array of microscopic lesions was observed, and lung, lymph nodes, spleen, and liver were the most consistently and severely affected organs (Table 2). All animals
Table 2. Main Microscopic Findings in the Lung, Pulmonary and Mediastinal Lymph Nodes, and the Liver of 29 Guiana Dolphins (Sotalia guianensis) Included in This Study.

\begin{tabular}{|c|c|}
\hline Microscopic findings & $\mathrm{Af} / \mathrm{Ev}(\%)$ \\
\hline \multicolumn{2}{|l|}{ Lung } \\
\hline Verminous pneumonia (Halocercus brasiliensis) & $22 / 27(8 I)$ \\
\hline Pneumocyte type II hyperplasia & $18 / 27(67)$ \\
\hline Multinucleate giant cells/syncytia & $13 / 27(48)$ \\
\hline Bacteria & $4 / 27(15)$ \\
\hline Intranuclear and intracytoplasmic inclusion bodies & $3 / 27(11)$ \\
\hline Interstitial + aspiration pneumonia/squames (calf) & $3 / 27(11)$ \\
\hline Pulmonary mycosis & $2 / 27(7)$ \\
\hline Toxoplasma gondii & $1 / 27(4)$ \\
\hline Interstitial pneumonia & $\mathrm{I} / 27(4)$ \\
\hline \multicolumn{2}{|l|}{ Pulmonary/mediastinal lymph nodes } \\
\hline Lymphoid depletion & $20 / 26(8 I)$ \\
\hline Eosinophilic lymphadenitis & $17 / 26(76)$ \\
\hline Histiocytosis & $1 \mathrm{I} / 26(52)$ \\
\hline Hemosiderosis & $9 / 26(43)$ \\
\hline Multinucleate/syncytia & $6 / 26(29)$ \\
\hline Nematode larvae & $4 / 26(19)$ \\
\hline Fibrosis & $3 / 26(14)$ \\
\hline Lymphocytolysis & $2 / 26(9)$ \\
\hline Toxoplasma gondii & $\mathrm{I} / 26(5)$ \\
\hline \multicolumn{2}{|l|}{ Other lymph nodes ${ }^{a}$} \\
\hline Lymphoid depletion & $13 / 15(87)$ \\
\hline Histiocytosis & $12 / 15(80)$ \\
\hline Eosinophilic lymphadenitis & $7 / 15(47)$ \\
\hline Hemosiderosis & $7 / 15$ (47) \\
\hline Multinucleate/syncytia & $6 / 15(40)$ \\
\hline Lymphocytolysis & $3 / 15(20)$ \\
\hline Ciliate protozoa & $1 / 15(7)$ \\
\hline Bacteria & $1 / 15(7)$ \\
\hline \multicolumn{2}{|l|}{ Liver } \\
\hline Pericholangitis & $8 / 24(33)$ \\
\hline Cholestasis & $8 / 24(33)$ \\
\hline Vacuolar degeneration & $6 / 24(25)$ \\
\hline Bile duct hyperplasia & $5 / 24(2 I)$ \\
\hline Lipidosis & $3 / 24(12)$ \\
\hline Hemosiderosis & $3 / 24(12)$ \\
\hline Toxoplasma gondii & $2 / 24(8)$ \\
\hline Endarteritis & $2 / 24(8)$ \\
\hline Hepatocellular dissociation & $1 / 24(8)$ \\
\hline
\end{tabular}

Abbreviations: Af, affected animals; Ev, evaluated animals.

${ }^{a}$ Includes prescapular, mesenteric, hepatic, pancreatic, retroperitoneal, lymph nodes.

had pneumonia, and lesions associated with $H$. brasiliensis infection (81\%) overlapped CeMV-associated lesions (Fig. 1). CeMV-associated lesions were acute/subacute bronchointerstitial to interstitial pneumonia with type II pneumocyte hyperplasia (67\%), multinucleated cells (48\%), and intranuclear and/or intracytoplasmic inclusion bodies (11\%). Extrapulmonary CeMV-associated findings included lymphoid depletion in the lymph nodes, spleen, and thymus (87\%) with sinus histiocytosis $(80 \%)$; focal lymphocytic leptomeningitis in the cerebrum $(2 / 12 ; 17 \%)$; and occasional systemic multinucleated cells and intranuclear and/or intracytoplasmic inclusion bodies within epithelial and lymphohistiocytic cells. 


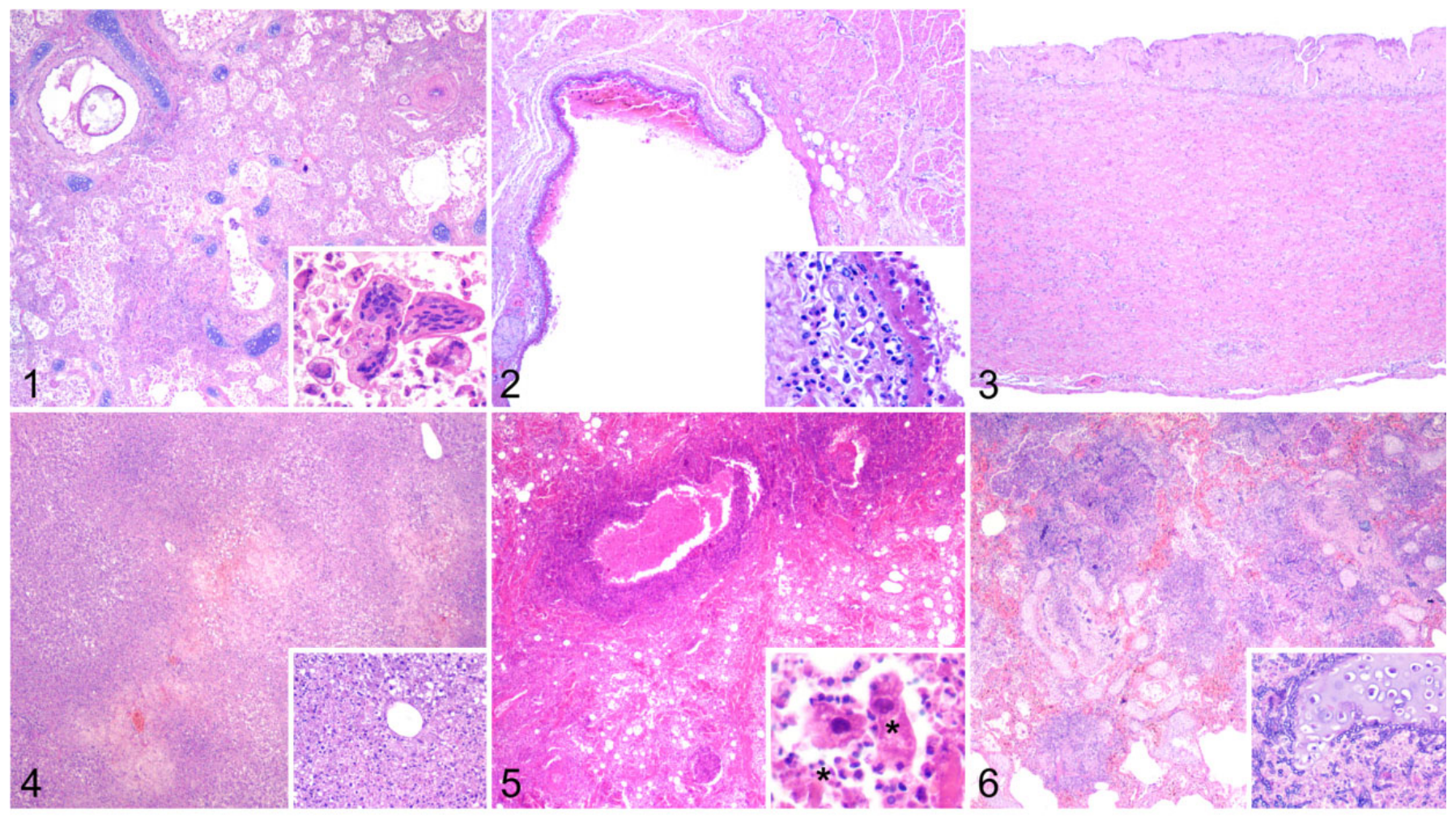

Figures I-6. Microscopic findings in Guiana dolphins with cetacean morbillivirus infection. Figure I. Lung, case 27. Marked, chronic bronchointerstitial pneumonia with thickening and hypercellularity of alveolar septa, multinucleated cells (inset), and intrabronchiolar Halocercus brasiliensis. Hematoxylin and eosin (HE). Figure 2. Heart, case 29. Focally extensive, acute eosinophilic coronary endophlebitis (inset). HE. Figure 3. Pulmonary artery, case 28. Chronic fibrosing pulmonary endarteritis. HE. Figure 4. Liver, case 25. Multifocal, random acute necrotizing hepatitis (inset). HE. Figure 5. Skin, case 18. Thromboembolic cutaneous ciliate protozoosis. HE. Inset: Intralesional ciliated protozoa (asterisks). HE. Figure 6. Lung, case 25. Marked, multifocal, chronic fibrinosuppurative and necrotizing bronchopneumonia with fungal masses. Inset: Hyphae with invasion of cartilage. HE.

Halocercus brasiliensis-associated lesions included chronic fibrosing bronchointerstitial pneumonia with remodeling, bronchial/bronchiolar sclerosis, proliferative (fibro-villous) pleuritis, and tunica media hyperplasia with stenosis, angiomatosis, and eosinophilic proliferative pulmonary endarteritis or endophlebitis. The latter was also noted in the ascending aorta, coronary arteries, and coronary veins (Fig. 2), as well as in pulmonary and intrahepatic arteries with distinct early (Supplemental Fig. S10), subacute (Supplemental Fig. S11), and chronic stages (Fig. 3). Migrating H. brasiliensis larvae were associated with nodular to diffuse eosinophilic lymphadenitis with necrosis $(76 \%)$ and with nephritis (4\%). Additional findings were poxviral dermatitis $(5 / 29 ; 17 \%$; the cases tested were PCR-negative; Supplemental Fig. S12); herpesvirus-like skin lesions $(5 / 29 ; 17 \%$; the cases tested were PCR-negative); multisystemic toxoplasmosis (3/29; $10 \%), 2$ of which were confirmed by IHC and PCR analyses (Fig. 4); multisystemic ciliated protozoosis (2/29; 7\%; Fig. 5), one of which was coinfected with bacilli; disseminated mycosis $(2 / 29 ; 7 \%$; Fig. 6$)$; and bacterial cutaneous and systemic disease $(1 / 29 ; 3 \%)$. Additional gross and microscopic findings are summarized in Table 2 and Supplemental Table S3.
Twenty-seven of 29 (93\%) dolphins had detectable morbilliviral antigen (MA). The antigen was observed in numerous tissues and cell types (Table 3). MA was found in epithelial cells, infiltrating mononuclear inflammatory cells, and interstitial mesenchymal cells, most resembling fibroblasts, throughout the digestive system involving the tongue, oropharynx, salivary gland (Fig. 7), esophagus (Fig. 8), stomach (Fig. 9), small intestine (Fig. 10), and large intestine (Supplemental Fig. S13). The gut-associated lymphoid tissue was often involved, as well as neuronal somata of the submucosal and myenteric plexi of the stomach, small intestine, and large intestine. In the hepatobiliary system, MA was mostly confined to the bile duct epithelium (Supplemental Fig. S14), Kupffer cells, and circulating mononuclear cells (mainly monocytes and lymphocytes). The pancreas had MA in exocrine acinar and ductal epithelium (Fig. 11), in mononuclear inflammatory cells, and in interstitial mesenchymal cells.

In the lung, immunolabeling was most intense in hyperplastic type II pneumocytes, alveolar macrophages, and multinucleated cells. There was also widespread intraepithelial MA in the trachea, bronchi, bronchioles, and alveoli (Supplemental Fig. S15), as well as in parenchymal mononuclear inflammatory cells or interstitial mesenchymal cells and circulating 
Table 3. Morbilliviral Antigen Distribution Frequency by Organ/Tissue and Cell Type in 29 Guiana Dolphins (Sotalia guianensis).

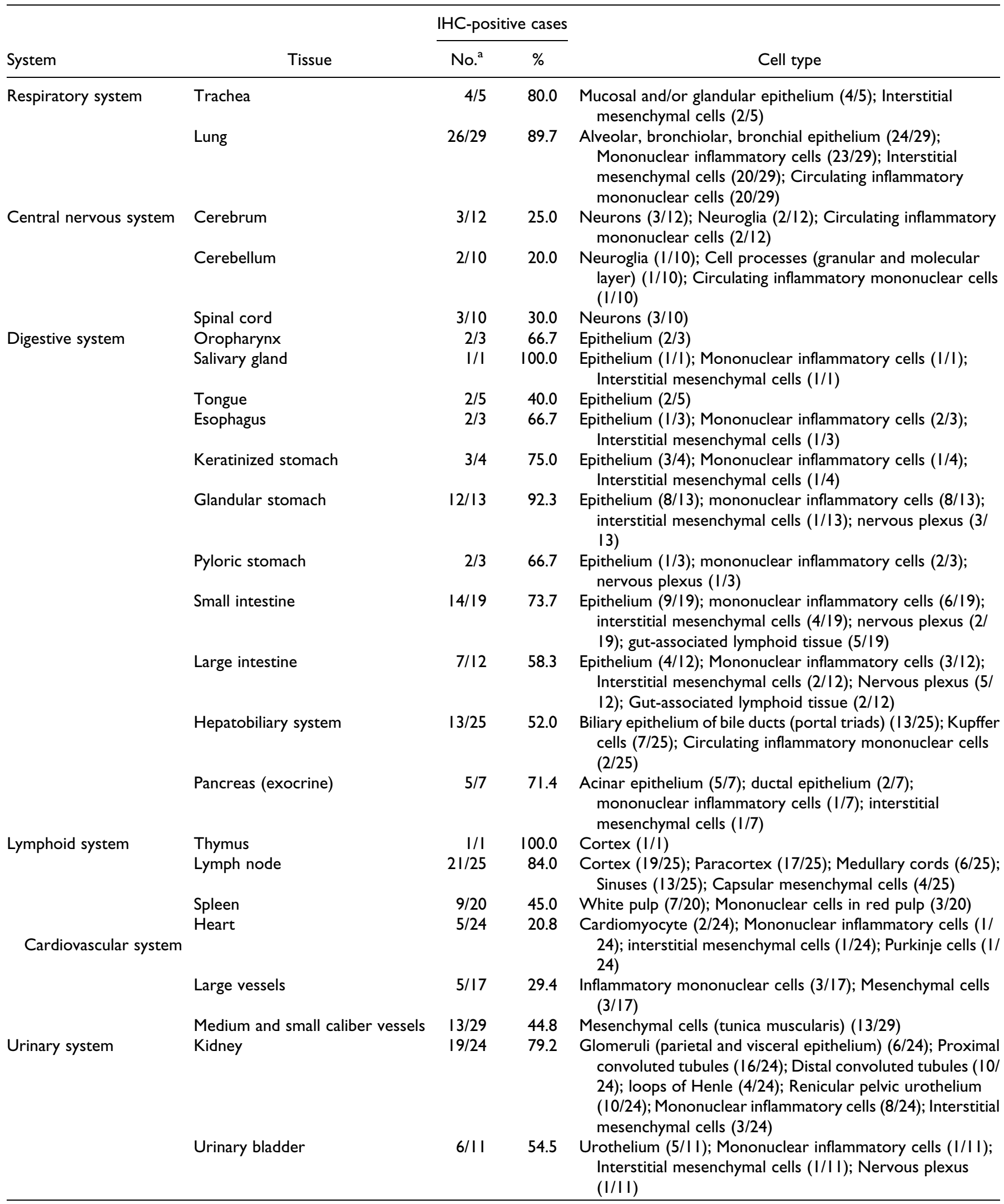


Table 3. (continued)

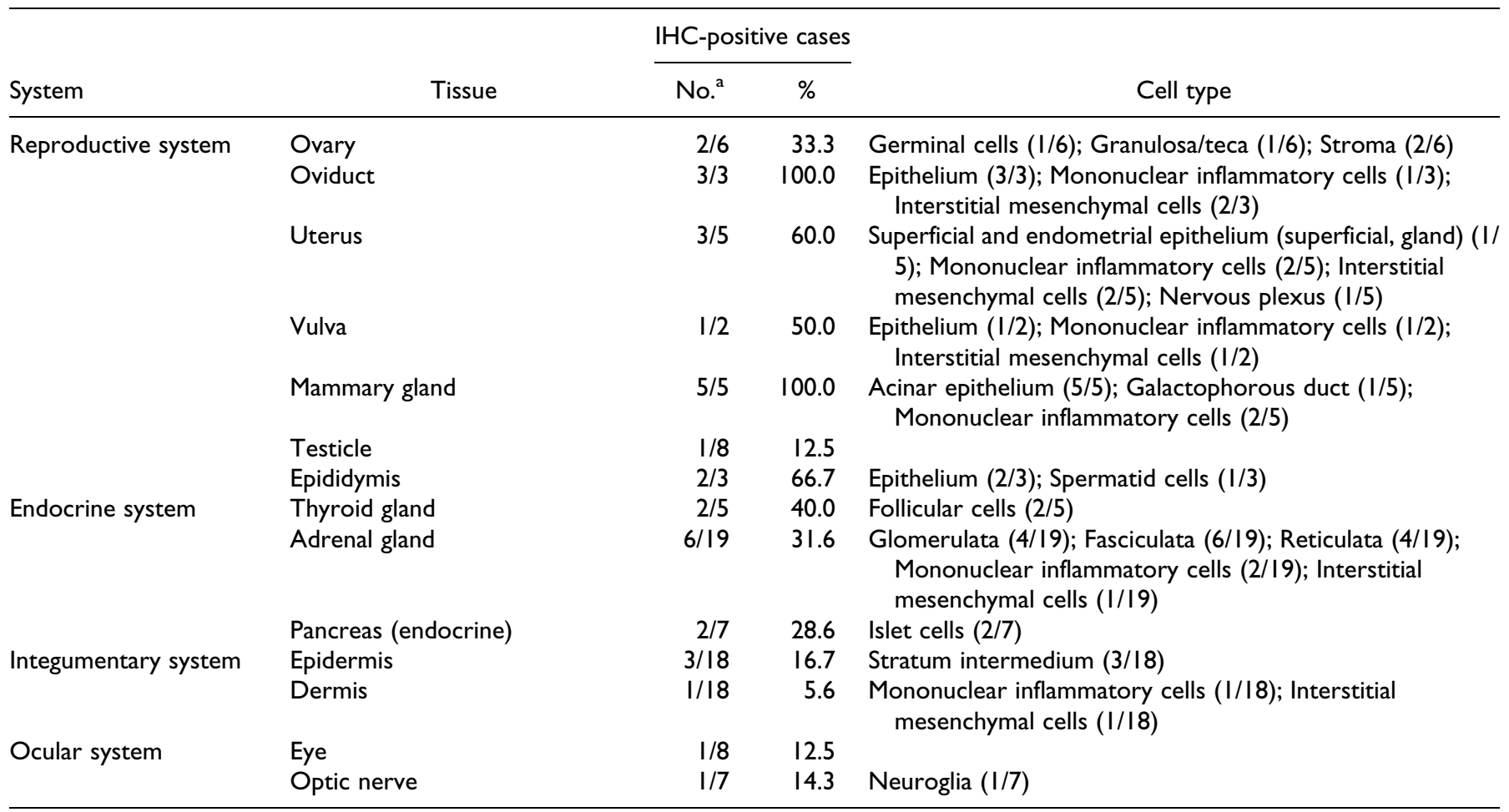

${ }^{a}$ Denominator indicates the number of cases in which the tissue in question was available for study.

mononuclear cells. In case 2, dual IHC revealed most lung multinucleated cells were AE1/AE3-positive and coexpressed MA (Fig. 12). Fewer intra-alveolar multinucleated cells co-expressed Iba1 and MA (Fig. 13).

There was abundant MA in lymphocytes and histiocytes throughout the lymphoid system. Positive mononuclear cells were detected in the cortex, medulla, and Hassall's corpuscles of the thymus; in the cortex, paracortex, medullary cords, sinuses, and capsular mesenchymal cells of lymph nodes (more abundant in mediastinal lymph nodes; Supplemental Fig. S16); and in the white and red pulp of the spleen. In lymph node and spleen, multinucleated cells co-expressed Iba1 and CeMV (Fig. 14). No multinucleated cells co-expressing AE1/AE3 and CeMV were noted in these tissues.

In the kidney, MA was detected in the parietal and visceral epithelium of glomeruli, proximal and distal convoluted tubules (Supplemental Fig. S17), loops of Henle, pelvic urothelium, and in mononuclear inflammatory cells and interstitial mesenchymal cells (Supplemental Fig. S18). Four distinct immunolabeling patterns were noted in the renal tubules: intense and diffuse cytoplasmic, finely granular cytoplasmic, coarsely granular cytoplasmic, and diffuse cytoplasmic in intratubular cellular casts. MA was also noted in the urinary bladder urothelium (Supplemental Fig. S19), mononuclear inflammatory cells, interstitial mesenchymal cells, and submucosal plexi. A few cases had MA in cardiomyocytes, interstitial mesenchymal cells, and Purkinje cells (Fig. 15), as well as mononuclear inflammatory cells and interstitial mesenchymal cells of large vessels and pericytes/arteriolar smooth muscle cells of the tunica media in medium and small caliber vessels, including some aortic and pulmonary vasa vasorum (Supplemental Fig. S20). A few cases had MA in the central nervous system (CNS). Cases 1, 20, and 25 had labeling in neurons, neuroglia, and circulating mononuclear cells in the cerebrum; neuroglia, circulating mononuclear cells, and neuron cell processes of the granular and molecular layers in the cerebellum; and neurons in the spinal cord. MA was detected in primordial follicles, specifically granulosa/ theca cells, and stromal mesenchymal cells (Supplemental Fig. S21), as well as in the oviduct/endometrium and vulvar epithelium, mononuclear inflammatory cells, interstitial mesenchymal cells, and associated plexi. A few males had MA in epididymis epithelium (Fig. 16). The mammary gland had abundant MA in acinar and galactophorous duct epithelium, mononuclear inflammatory cells and interstitial mesenchymal cells. The thyroid gland, adrenal gland (Fig. 17), and pancreatic islets had MA mostly in epithelial cells, and to a lesser extent in mononuclear inflammatory cells and interstitial mesenchymal cells. In the adrenal gland, MA was observed in foci of necrosis in the zona glomerulosa, zona fasciculata, and zona reticularis, or diffusely, associated with necrotizing cortical adrenalitis. Some cases had MA in all strata of the epidermis and mononuclear inflammatory cells and interstitial mesenchymal cells in the dermis/blubber (Fig. 18). One dolphin had MA in the optic nerve and cells of the retina. 


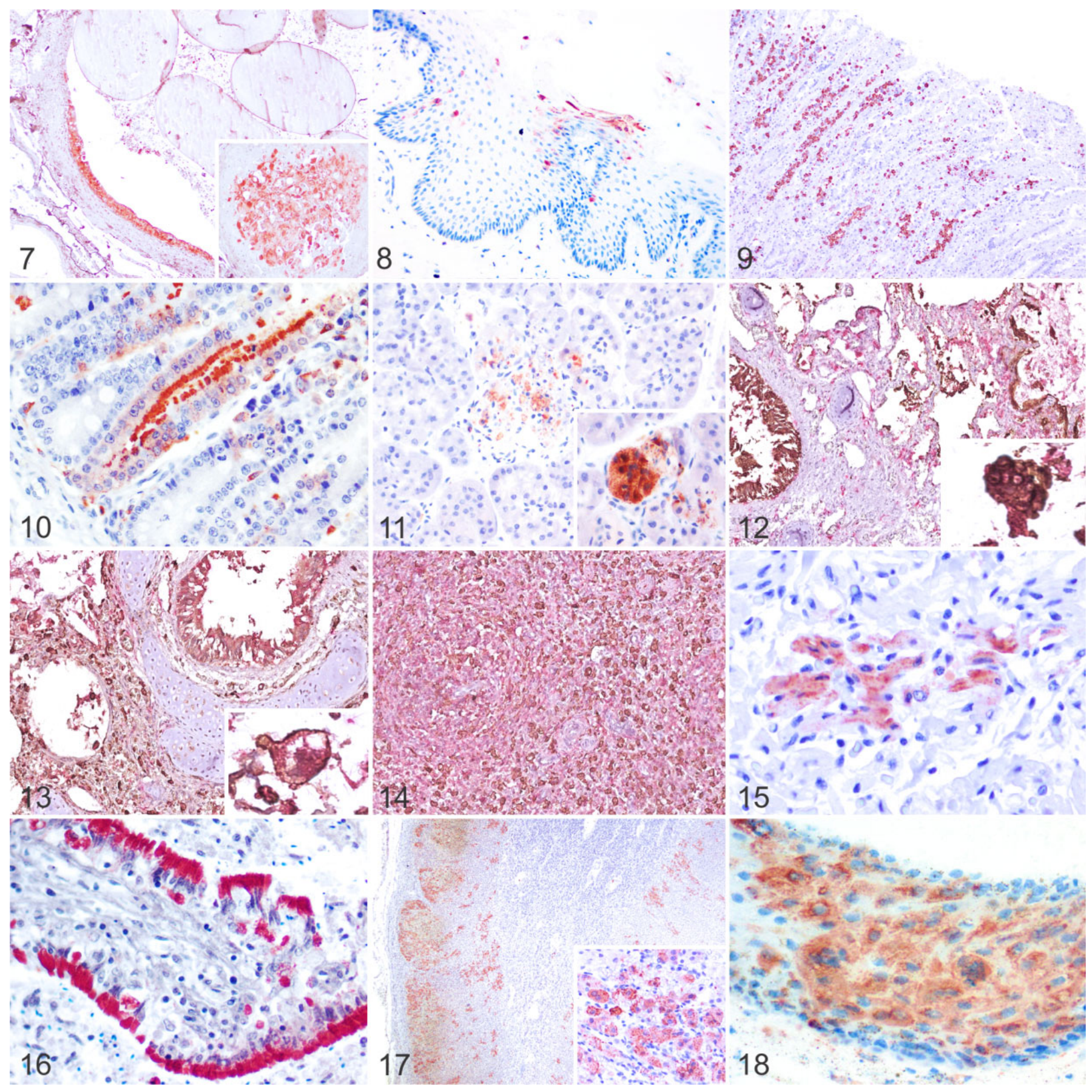

Figures 7-18. Cetacean morbillivirus infection, Guiana dolphins. Immunohistochemistry for morbillivirus using an antibody to canine distemper virus nucleoprotein. Figure 7. Salivary gland, case 22. There is abundant morbilliviral antigen (MA) in the epithelium. Inset: Strong immunolabeling in superficial ductal keratinocytes and macrophages. Figure 8. Esophagus, case 10. Abundant MA in scattered epithelial cells. Figure 9. Pyloric gastric chamber, case I. Abundant MA in glandular epithelium. Figure 10. Small intestine, case 2. MA in epithelium, infiltrating inflammatory mononuclear cells, and interstitial mesenchymal cells. Figure I I. Pancreas, case 2. MA in acinar epithelium, islets (inset), mononuclear inflammatory cells and interstitial mesenchymal cells. Figure 12. Lung, case 2. Co-localization of MA (red) and cytokeratin AEI/AE3 (brown) in epithelial cells, including a few multinucleated cells (inset). Double IHC including fast red (CDV) and brown (DAB; cytokeratin AEI/AE3). Figure 13. Lung, case 2. Co-localization of MA (red) and lbal (brown) in histiocytes, including a few multinucleated cells (inset). Double IHC including fast red (CDV) and brown (DAB; Ibal). Figure I4. Spleen, case 2. Co-localization of MA (red) and Iba I (brown) in histiocytes. Double IHC including fast red (CDV) and brown (DAB; Iba I). Figure I5. Heart, case I0. MA in cardiomyocytes. Figure 16. Epididymis, case 22. Abundant MA in epithelium of the epididymis. Figure I7A. Adrenal gland, case 2. Abundant MA in cells of the zona glomerulosa and zona fasciculata (inset), and to a lesser extent, in the zona reticularis. Figure I8A. Skin, case I0. Abudant MA in the epidermis. 


\section{Molecular Investigations}

All 29 dolphins tested PCR positive for CeMV (including one or more lung, spleen or lymph node, liver, kidney, and brain; Supplemental Table S2), and sequencing of partial phosphoprotein gene confirmed $99 \%$ to $100 \%$ identity of the amplicon to GD-CeMV. ${ }^{31,33}$ We obtained 2 identical novel partial sequences of the nucleoprotein gene (GenBank accession number MT163269) from lung samples of cases 9 and 17. The 289bp amplified fragment of the GD-CeMV nucleoprotein gene revealed $79 \%$ to $83 \%$ nucleotide identity to CeMV and other morbillivirus species, while the translated sequence of 93 amino acids was $98 \%$ to $100 \%$ similar to other CeMV. Phylogenetic analysis of the nucleotide sequence further corroborated that the GD-CeMV strain differed from other morbilliviruses and represented a distinct lineage (Supplemental Fig. S22). Toxoplasma gondii was molecularly confirmed in cases 14 (liver, lung, brain) and 15 (brain; 2/29; 7\%). No cetaceanpoxvirus or herpesvirus DNA were detected in the skin lesions examined. Brucella sp. was detected in the liver in case $17(1 / 29 ; 3 \%)$.

\section{Routine Microbiology}

Klebsiella pneumoniae was cultured from mediastinal exudate and bronchial exudate in cases 1 and 29, respectively, and Escherichia coli and Penicillium sp. from bronchial exudate in case 25 . The $E$. coli isolate was resistant to sulfamethoxazoletrimethoprim and cephalexin. There was no growth after 48 hours in urine from case 2 (Supplemental Table S2).

\section{Discussion}

Here we report the pathologic, IHC, and molecular findings in 29 Guiana dolphins that succumbed during an UME in Brazil (2017-2018). These results delineate the pathologic signature of epizootic GD-CeMV in Guiana dolphins. All these dolphins had either acute systemic or subacute systemic CeMVassociated disease presentations based on histopathologic, IHC, and PCR results. ${ }^{68}$

There are no pathognomonic gross lesions in CeMVinfected cetaceans. The gross lesions are largely nonspecific and often are the result of secondary infections. ${ }^{22,23}$ Previous studies reported mainly pulmonary, lymphoid, cerebral, and upper digestive alterations in DMV-infected striped dolphins (Stenella coeruleoalba) in the Mediterranean Sea during epizootic events. ${ }^{22,23}$ Most of those pulmonary changes were common in this cohort of Guiana dolphins; however, preexisting lung disease caused by $H$. brasiliensis made interpretation of the lung changes more challenging.

Our results indicate that $H$. brasiliensis is associated with significant pulmonary morbidity in Guiana dolphins, characterized by chronic fibrosing bronchointerstitial pneumonia with fibro-villous pleuritis. Other lesions attributed to $H$. brasiliensis were abdominal serositis, multicentric eosinophilic lymphadenitis and splenitis, and systemic vasculitis. ${ }^{33}$
The severity of these lesions, particularly in the lung, may have contributed to pulmonary dysfunction and compromised resilience to morbilliviral infection. The host and geographic range for this nematode is not fully known; however, it affects multiple cetacean species with variable pathogenicity. ${ }^{34,52}$

Other extrapulmonary gross findings observed in Guiana dolphins, such as cavitary effusion, icterus, hepatic lipidosis, lymphadenomegaly, and gastrointestinal parasitosis, have been described in epizootic DMV-infected striped dolphins. ${ }^{2,23}$ Exacerbated parasitism may be linked to DMV infection. ${ }^{3}$ Erosions and ulcers throughout the upper digestive system were relatively common in these dolphins, agreeing with observations in other delphinids. ${ }^{22,23}$ Similar to previous epizootics in other geographic locations, ${ }^{22,23,39,61}$ most Guiana dolphins had poor body condition. We surmise that the suboptimal nutritional status may be a preexisting condition and not necessarily a consequence of CeMV infection given the acute or subacute nature of the disease; however, we cannot entirely rule out a rapidly progressive deterioration linked to energetic demands in the aquatic environment. Cytokine-associated effects, such as those involving tumor necrosis factor, could be associated with wasting even in acute systemic or subacute systemic cases. Further research to investigate and characterize CeMV disease-associated cytokine profiles is warranted. Finally, we found 2 novel gross pathologic findings in this species unrelated to CeMV-infection: bilaterally symmetric pulmonary hemorrhagic necrosis and aortic valvular dysplasia. A cause for the former was not readily apparent, and the latter was incidental.

The distribution of MA was investigated in a wide set of tissues to determine the types of target cells naturally infected by this GD-CeMV strain and to correlate the presence of MA with lesions. This virus showed remarkable cellular pleiotropism, with similarities to some terrestrial morbilliviruses ${ }^{1,9,76}$ and other CeMV strains, ${ }^{68}$ but with some differences. This GD-CeMV strain had a remarkable pneumotropism and lymphotropism with wide replication in the lower airways and marked destruction of lymphocytes in all lymphoid organs. Primary (eg, thymus), secondary (ie, lymph nodes, spleen), and tertiary (mucosa-associated lymphoid tissue) lymphoid organs were main targets of GD-CeMV with abundant and widespread MA distribution within lymphocytes and histiocytes. MA was detected in epithelia, multinucleated cells, and resident lymphoid populations, as well as in circulating mononuclear cells (blood vessels and lymphatics) in virtually all organs evaluated. Detection of circulating mononuclear cells, largely monocytes/macrophages and lymphocytes, provided evidence for "leukocyte trafficking" as a major mechanism of morbilliviral spread within the host. Also, there was frequent MA in mononuclear inflammatory cells, interstitial mesenchymal cells, endothelia, and pericytes or smooth muscle cells of blood vessels, suggesting that the morbillivirus may need to cross the vessel wall for viral pleiotropic spread.

In this study, MA was also detected in the heart, within cardiomyocytes, interstitial mesenchymal cells, and Purkinje cells. Viral antigen is commonly detected in endothelial cells 
and cardiomyocytes in measles morbillivirus $(\mathrm{MeV})^{43}$ and rinderpest morbillivirus (RPV) infections ${ }^{76}$ but is rare in CDV and phocine morbillivirus (phocine distemper virus, PDV) infections despite myocardial necrosis. ${ }^{37}$

Acute fatal CeMV infection is associated with severe multifocal to diffuse bronchointerstitial to interstitial pneumonia with type II pneumocyte hyperplasia, generalized lymphoid depletion, and nonsuppurative encephalitis with multiorgan syncytial cells and intranuclear and/or intracytoplasmic inclusion bodies in epithelia and syncytial cells. ${ }^{22,23,42,46,61,65,66}$ In subacute systemic disease, animals that survive the acute systemic infection may succumb to opportunistic infections due to profound immunosuppression. Some of the typical lesions of acute systemic infection may no longer be present or be largely obscured by the inflammatory response to the opportunistic pathogens. ${ }^{22,39,65}$

While findings in the respiratory and lymphoid systems were similar to previous reports of morbillivirus infection in terrestrial mammals ${ }^{1,9,76}$ and other marine mammals, ${ }^{22-24,39,42,46,61}$ Guiana dolphins in this outbreak largely lacked degenerative, reactive, or inflammatory changes within the CNS, suggesting low neurovirulence of this strain or in this epidemic context. MA detection in CNS (neuronal and neuroglial cell elements) was limited to 3 dolphins out of 16 cases with CNS examined. These findings differ from DMV, PMV, and PWMV infections. ${ }^{68}$ It is conceivable that CNS involvement occurs at a later stage of infection, as described with CDV in dogs, and that these animals succumbed too early for CNS lesions to be observed. ${ }^{72}$ Hostrelated and pathogen-related determinants, along with environmental factors, could have influenced GD-CeMV neurotropism in this group of animals. While all morbilliviruses transiently infect the CNS in their natural hosts, development of disease may depend on the efficiency of the immune response, abundance of receptors, and the efficacy of specific viral replication and perpetuation mechanisms. ${ }^{13}$

This study also indicates GD-CeMV targets the peripheral nervous system, specifically autonomic nerves of the gastrointestinal and reproductive systems. A potential role for peripheral nervous system involvement in morbilliviral diseases of terrestrial mammals has received little attention. Future studies may be aimed at characterizing the peripheral nervous system neuronal and neuroglial cell populations in CeMV infection.

To the authors' knowledge, this study provides the first documentation of CeMV replication (suggested by nucleoprotein detection) in salivary gland, optic nerve, heart, diaphragm, parietal and visceral epithelium of glomeruli, vulva, and thyroid gland. MA has been detected in thyroid glands of monkeys and cattle experimentally infected with $\mathrm{MeV}^{35}$ and RPV, ${ }^{76}$ respectively. Also, MA has been detected in adrenal gland of dogs, humans, and cattle infected by $\mathrm{CDV}, \mathrm{MeV}$, and RPV, respectively. ${ }^{10,30,76,77}$ In cetaceans, MA in adrenal gland has been reported in short-finned pilot whales (Globicephala macrorhynchus) and Black Sea common dolphin (Delphinus delphis ponticus) infected by PWMV and DMV, respectively, although pathologic details were not available. ${ }^{7,63} \mathrm{We}$ demonstrated MA in areas of adrenocortical cell necrosis, supporting a virus-associated cytopathogenic effect of this GDCeMV strain. The clinicopathologic relevance of this lesion is unclear.

Abundant MA in the epithelium of salivary glands, oral cavity, glandular stomach, small and large intestines, pancreatic acini, and bile ducts may be found in some terrestrial MVs, such as, MeV, CDV, RPV, and small ruminant morbillivirus (peste-des-petits-ruminants virus, PPRV). ${ }^{1,9,30,35,76} \mathrm{We}$ also detected MA in the skin and along mucocutaneous junctions with similarities to $\mathrm{MeV}, \mathrm{CDV}$, and RPV infections. ${ }^{1,9,49,76}$ Transmission of CeMV by direct skin contact remains to be proven; however, these findings suggest that infected skin could be a potential source of virus.

These findings suggest possible mechanisms for viral shedding and transmission. While previous reports suggest that the respiratory system is the major route of transmission in CeMV infections, our results suggest that the gastrointestinal and urinary systems may have also played important roles in viral shedding during this UME. The large amount and widespread distribution of MA in these systems, primarily in epithelial cells, indicate body secretions bearing desquamated epithelial cells are likely a significant source of infective virus. ${ }^{76}$ Also, MA has been detected in reproductive tissue of several cetacean species ${ }^{7,22,41,45,61,63}$ and a number of domesticated and wildlife species. ${ }^{36,40,50,51,75}$ Demonstration of viral replication in reproductive structures, including male and female gonads, lends support to venereal transmission and potential vertical in utero and ex utero transmission of GD-CeMV. These routes likely played a role during this particular UME in Brazil and should be considered during epidemiologic investigations of future outbreaks.

Fatal coinfections in this set of Guiana dolphins infected by GD-CeMV included disseminated toxoplasmosis, systemic mycosis, systemic ciliated protozoosis, and bacterial disease. Most of these agents are known to cause significant morbidity and mortality in CeMV-infected delphinids, particularly in subacute systemic and chronic systemic CeMV infections. ${ }^{68}$ In this outbreak, immunosuppression by GD-CeMV and environmental pollutants (unpublished data, Lailson-Brito) could have predisposed to the secondary infections. Toxoplasmosis is a common coinfecting pathogen in dolphins with CeMV infection, and to a lesser extent, in whales. ${ }^{18,22,23,39,46,61}$ In cetaceans from Brazil, $T$. gondii has been described in 3 Guiana dolphins, an Atlantic bottlenose dolphin, a captive killer whale (Orcinus orca), and a Bryde's whale (Balaenoptera edeni). ${ }^{4,14,18,29}$ Seropositivity has been detected in free-living Amazon river dolphins (Inia geoffrensis) ${ }^{58}$ Freshwater runoffs with cat feces or soil contaminated with oocysts from coastal terrestrial areas are possible sources of $T$. gondii in the marine environment. Our findings with $3(10 \%)$ Guiana dolphins infected by $T$. gondii widen the geographic range of $T$. gondii occurrence in this species and call attention to biological pollution in Ilha Grande and Sepetiba Bays.

Concurrent mycosis is also common in dolphins infected by CeMV. ${ }^{12,22,39}$ Histomorphological characteristics of fungal 
elements in this study were most compatible with mucormycosis. Cutaneous ciliated protozoosis was a common comorbidity in bottlenose dolphins during the 1987-1988 US Atlantic coast epizootic. ${ }^{61}$ Cutaneous, fascial, muscular, and lymph node ciliated protozoosis were observed in 2 cases. Although they were likely opportunistic pathogens of ulcerated lesions, ${ }^{61}$ these ciliates were associated with severe multisystemic thromboembolic disease with major cutaneous injury. Additionally, we detected a dolphin coinfected with Brucella sp., expanding the geographic range for this pathogen in South American marine mammals. ${ }^{2,56,57}$ Additional confirmed bacterial coinfections were Klebsiella pneumoniae in mediastinal exudate and bronchial exudate of cases 1 and 29, respectively, and $E$. coli in bronchial exudate of case 25 . The E. coli isolate was resistant to sulfamethoxazole-trimethoprim combination and cephalexin. Resistance of $E$. coli strains to these antibiotics has been documented in free-ranging and captive dolphins. ${ }^{47,60}$ Penicillium sp. likely represented an environmental contaminant rather than a pathogen in the latter case.

Cutaneous poxvirosis and herpesvirosis may be associated with poor environmental conditions and weakened immunity. ${ }^{69}$ We found classic "tattoo-like skin lesions" attributed to cetaceanpoxvirus and skin lesions, primarily "punctate ulcerated lesions," that have been linked to cetacean herpesvirus. ${ }^{54,55}$ Cutaneous poxvirosis was suspected grossly and/or microscopically in 5 dolphins; however, molecular confirmation was not achieved in the 3 tested by PCR. Cetaceanpoxvirus has been reported in a wide spectrum of hosts, and in Brazil, molecularly confirmed cases are limited to bottlenose dolphins and Guiana dolphins. ${ }^{55}$ Herpesvirus has been previously described in 2 Guiana dolphins, ${ }^{54,62}$ but infection was not confirmed in the 3 cases tested in this study. The significance of these potential viral coinfections with CeMV is unknown.

Potential cyclicity of GD-CeMV epizootics is of concern for South American cetacean biodiversity and conservation efforts. When naïve populations are exposed to CeMV by an enzootically infected species, epizootics with high mortality have ensued. ${ }^{22,23,61}$ High susceptibility and mortality as well as similar pathologic features and transmission mechanisms have been described in various free-ranging terrestrial species for $\mathrm{RPV}$ and $\mathrm{CDV} .{ }^{74} \mathrm{~A}$ long-term, large-scale study found molecular and IHC evidence of small epidemics (affecting less than 5 dolphins) and single cases of endemic GD-CeMV disease in Brazil as far back as 1996 (unpublished data, Groch). The epidemiology and viral dynamics of this recent UME continue to be investigated.

Current knowledge of the GD-CeMV genome is limited to small fragments of the phosphoprotein and large protein genes. Here we reported a novel partial sequence of the nucleoprotein gene. A nucleotide identity of $79 \%$ to $83 \%$ to other CeMV further corroborates that this is a novel CeMV lineage. However, the nucleoprotein gene partial sequence has shown a higher protein homology ( $98 \%$ aa identity) to other CeMV when compared to the phosphoprotein gene $(69 \%$ to $72 \%)$ and large protein gene $(85 \%$ to $89 \%){ }^{33}$ The differences in identity of nucleotides and amino acids can be explained by differences in DNA sequences that code for similar proteins. The higher similarity between proteins suggests higher homology of GD-CeMV and other CeMV. Due to protein conservation, this region may be suitable for investigation of remote evolutionary relationships.

In summary, we reported comprehensive pathologic, IHC, and molecular results concerning GD-CeMV infection in 29 Guiana dolphins that succumbed during an UME in Brazil (2017-2018). CeMV-associated lesions were observed in all PCR and/or IHC-confirmed animals; however, they were variably overlapped by concurrent disease processes. GD-CeMV demonstrated remarkable pneumotropism and lymphotropism with little neurotropism. Preexisting Halocercus brasiliensis pneumonia likely predisposed to and aggravated morbidity of morbilliviral pneumonia. Additional relevant comorbidities included disseminated toxoplasmosis, multisystemic mycosis, multisystemic ciliated protozoosis, and bacterial disease, including one case with Brucella sp. Our results delineate the pathologic findings in GD-CeMV in Guiana dolphins, contribute to the body of knowledge on cetacean pathology, and may prove of value to first responders, clinicians, rehabilitators, and diagnosticians working in the cetacean health field.

\section{Acknowledgements}

The authors would like to thank the Laboratório de Mamíferos Aquáticos e Bioindicadores (MAQUA/UERJ) team for assistance in stranding monitoring and necropsy procedures; Programa de Conservação dos botos-cinza (Sotalia guianensis) e outros cetáceos das baías da Ilha Grande e de Sepetiba (MAQUA/UERJ, Associação Cultural e de Pesquisa Noel Rosa, INEA, Transpetro), and Projeto de Monitoramento de Praias da Bacia de Santos (PMP-BS) (MAQUA/UERJ, CTA MeioAmbiente, Instituto Boto Cinza, Petrobras) for supporting cetacean research in the region. PMP-BS is a monitoring program that is part of the federal environmental licensing conducted by the Brazilian Institute of Environment and Renewable Natural Resources (IBAMA).

\section{Declaration of Conflicting Interests}

The author(s) declared no potential conflicts of interest with respect to the research, authorship, and/or publication of this article.

\section{Funding}

The author(s) disclosed receipt of the following financial support for the research, authorship, and/or publication of this article: We appreciate the support of Coordination for the Improvement of Higher Education Personnel (CAPES) and São Paulo Research Foundation (FAPESP), Research Grants \#2015/00735-6 and \#2017/24335-2. This study was designed and conducted in fulfillment with FAPESP postdoctoral fellowships \#2014/24932-2; \# 2015/05043-5 (KRG), and \#2017/02223-8 (JDD). JLCD and RMS are the recipients of a fellowship by the National Research Council (CNPq; Grants \#305349/20155 and \#310532/2017-5, respectively); AFA, JLB, and TLB have research grant from CNPq (PQ-1D, PQ-1C, and PQ-2, respectively), FAPERJ (CNE and JCNE,137, respectively), and UERJ (Prociência).

\section{ORCID iD}

Kátia R. Groch (D) https://orcid.org/0000-0002-2359-6391

Josué Díaz-Delgado (D) https://orcid.org/0000-0003-1216-5446

Ana I. Godinho (D) https://orcid.org/0000-0001-5549-8684 


\section{References}

1. Appel MJ. Pathogenesis of canine distemper. Am J Vet Res. 1969;30(7): 1167-1182.

2. Attademo FLN, Silva JCR, Luna FO, et al. Retrospective survey for pathogens in stranded marine mammals in northeastern Brazil: Brucella spp. infection in a Clymene dolphin (Stenella clymene). J Wildl Dis. 2018;54(1):151-155.

3. Aznar FJ, Perdiguero D, Perez del Olmo A, et al. Changes in epizoic crustacean infestations during cetacean die-offs: the mass mortality of Mediterranean striped dolphins Stenella coeruleoalba revisited. Dis Aquat Organ. 2005; 67(3):239-247.

4. Bandoli JG, Oliveira CAB. Toxoplasmose em Sotalia guianensis (Van Beneden, 1963, Cetacea-Delphinidae). Folha Med. 1977;75:459-458.

5. Barrett T, Visser IK, Mamaev L, et al. Dolphin and porpoise morbilliviruses are genetically distinct from phocine distemper virus. Virology. 1993;193(2): 1010-1012.

6. Batinga MCA, de Lima JTR, Gregori F, et al. Comparative application of IS711-based polymerase chain reaction (PCR) and loop-mediated isothermal amplification (LAMP) for canine brucellosis diagnosis. Mol Cell Probes. 2018; 39:1-6.

7. Birkun A Jr, Kuiken T, Krivokhizhin S, et al. Epizootic of morbilliviral disease in common dolphins (Delphinus delphis ponticus) from the Black Sea. Vet Rec. 1999;144(4):85-92.

8. Bracht AJ, Brudek RL, Ewing RY, et al. Genetic identification of novel poxviruses of cetaceans and pinnipeds. Arch Virol. 2006;151(3):423-438.

9. Brown CC, Mariner JC, Olander HJ. An immunohistochemical study of the pneumonia caused by peste des petits ruminants virus. Vet Pathol. 1991; 28(2): 166-170

10. Brown HR, Goller NL, Rudelli RD, et al. Postmortem detection of measles virus in non-neural tissues in subacute sclerosing panencephalitis. Ann Neurol. 1989; 26(2):263-268.

11. Budaszewski RF, Pinto LD, Weber MN, et al. Genotyping of canine distemper virus strains circulating in Brazil from 2008 to 2012. Virus Res. 2014;180: 76-83.

12. Cassle SE, Landrau-Giovannetti N, Farina LL, et al. Coinfection by Cetacean morbillivirus and Aspergillus fumigatus in a juvenile bottlenose dolphin (Tursiops truncatus) in the Gulf of Mexico. J Vet Diagn Invest. 2016;28(6):729-734.

13. Cosby SL, Duprex WP, Hamill LA, et al. Approaches in the understanding of morbillivirus neurovirulence. J Neurovirol. 2002;8(Suppl 2):85-90.

14. Costa-Silva S, Sacristan C, Gonzales-Viera O, et al. Toxoplasma gondii in cetaceans of Brazil: a histopathological and immunohistochemical survey. Rev Bras Parasitol Vet. 2019;28(3):395-402.

15. Cunha HA, Santos-Neto EB, Carvalho RR, et al. First Outbreak of Cetacean morbillivirus in the South Atlantic: Epidemiological Context Paper IWC/ SC67b/E14 Presented to the IWC Scientific Committee. International Whaling Commission; 2018.

16. de Vries RD, Duprex WP, de Swart RL. Morbillivirus infections: an introduction. Viruses. 2015;7(2):699-706.

17. Di Guardo G, Mazzariol S. Cetacean morbillivirus-associated pathology: knowns and unknowns. Front Microbiol. 2016;7:112.

18. Díaz-Delgado J, Groch KR, Ramos HG, et al. Fatal systemic toxoplasmosis by a novel non-archetypal Toxoplasma gondii in a Bryde's whale (Balaenoptera edeni). Front Mar Sci. Published online June 3, 2020. doi:10.3389/fmars. 2020.00336

19. Díaz-Delgado J, Groch KR, Ressio R, et al. Comparative immunopathology of Cetacean morbillivirus infection in free-ranging dolphins from western Mediterranean, northeast-central, and southwestern Atlantic. Front Immunol. 2019; 10:485.

20. Díaz-Delgado J, Groch KR, Sierra E, et al. Comparative histopathologic and viral immunohistochemical studies on CeMV infection among Western Mediterranean, Northeast-Central, and Southwestern Atlantic cetaceans. PLoS One. 2019;14(3):e0213363.

21. Domingo M, Ferrer L, Pumarola M, et al. Morbillivirus in dolphins. Nature 1990;348(6296):21
22. Domingo M, Visa J, Pumarola M, et al. Pathologic and immunocytochemical studies of Morbillivirus infection in striped dolphins (Stenella coeruleoalba). Vet Pathol. 1992;29(1):1-10.

23. Duignan PJ, Geraci JR, Raga JA, et al. Pathology of Morbillivirus infection in striped dolphins (Stenella coeruleoalba) from Valencia and Murcia, Spain. Can $J$ Vet Res. 1992;56(3):242-248.

24. Duignan PJ, Van Bressem MF, Baker JD, et al. Phocine distemper virus: current knowledge and future directions. Viruses. 2014;6(12):5093-5134.

25. Ehlers B, Dural G, Yasmum N, et al. Novel mammalian herpesviruses and lineages within the Gammaherpesvirinae: cospeciation and interspecies transfer. J Virol. 2008;82(7):3509-3516.

26. Flach L, Alonso MB, Marinho T, et al. Clinical signs in free-ranging Guiana dolphins (Sotalia guianensis) during a Morbillivirus epidemic: a case study in Sepetiba Bay, Brazil. Dis Aquat Organ. 2019;133(3):175-180.

27. Frisk AL, König M, Moritz A, et al. Detection of canine distemper virus nucleoprotein RNA by reverse transcription-PCR using serum, whole blood, and cerebrospinal fluid from dogs with distemper. J Clin Microbiol. 1999;37(11): 3634-3643.

28. Geraci JR, Lounsbury VJ. Marine Mammals Ashore: A Field Guide for Strandings. National Aquarium in Baltimore; 2005

29. Gonzales-Viera O, Marigo J, Ruoppolo V, et al. Toxoplasmosis in a Guiana dolphin (Sotalia guianensis) from Parana, Brazil. Vet Parasitol. 2012;191(3-4): 358-362.

30. Green EC, Appel MJ. Canine distemper virus. In: Green EC, ed. Infectious Diseases of the Dog and Cat. WB Saunders; 1990:226-241.

31. Groch KR, Colosio AC, Marcondes MC, et al. Novel Cetacean morbillivirus in Guiana dolphin, Brazil. Emerg Infect Dis. 2014;20(3):511-513.

32. Groch KR, Kolesnikovas CKM, de Castilho PV, et al. Cetacean morbillivirus in Southern Right Whales, Brazil. Transbound Emerg Dis. 2019;66(1):606-610.

33. Groch KR, Santos-Neto EB, Díaz-Delgado J, et al. Guiana dolphin unusual mortality event and link to Cetacean morbillivirus, Brazil. Emerg Infect Dis. 2018;24(7):1349-1354.

34. Guimarães JP, Febronio AMB, Vergara-Parente JE, et al. Lesions associated with Halocercus brasiliensis Lins de Almeida, 1933 in the lungs of dolphins stranded in the Northeast of Brazil. J Parasitol. 2015;101(2):248-251.

35. Hall WC, Kovatch RM, Herman PH, et al. Pathology of measles in rhesus monkeys. Vet Pathol. 1971;8(4):307-319.

36. Hamir A, Raju N, Hable C, et al. Retrospective study of testicular degeneration in raccoons with canine distemper infection. J Vet Diagn Investig. 1992;4(2): 159-163.

37. Higgins RJ, Krakowka S, Metzler AE, et al. Canine distemper virus-associated cardiac necrosis in the dog. Vet Pathol. 1981;18(4):472-486.

38. Jo WK, Kruppa J, Habierski A, et al. Evolutionary evidence for multi-host transmission of Cetacean morbillivirus. Emerg Microbes Infect. 2018;7(1): $1-15$.

39. Kemper CM, Tomo I, Bingham J, Bastianello SS, Wang J, Gibbs SE, et al. Morbillivirus-associated unusual mortality event in South Australian bottlenose dolphins is largest reported for the Southern Hemisphere. R Soc Open Sci 2016: 3(12): 160838

40. Kennedy S, Kuiken T, Jepson PD, et al. Mass die-off of Caspian seals caused by canine distemper virus. Emerg Infect Dis. 2000;6(6):637

41. Kennedy S, Kuiken T, Ross H, et al. Morbillivirus infection in two common porpoises (Phocoena phocoena) from the coasts of England and Scotland. Vet Rec. 1992;131(13):286-290.

42. Kennedy S, Smyth JA, Cush PF, et al. Histopathologic and immunocytochemical studies of distemper in harbor porpoises. Vet Pathol. 1991;28(1):1-7.

43. Kimura A, Tosaka K, Nakao T, Measles rash . I. Light and electron microscopic study of skin eruptions. Arch Virol. 1975;47(4):295-307.

44. Kumar S, Stecher G, Tamura K. MEGA7: Molecular Evolutionary Genetics Analysis Version 7.0 for bigger datasets. Mol Biol Evol. 2016;33(7): 1870-1874.

45. Lipscomb TP, Kennedy S, Moffett D, et al. Morbilliviral disease in an Atlantic bottlenose dolphin (Tursiops truncatus) from the Gulf of Mexico. $J$ Wildl Dis. 1994;30(4):572-576 
46. Lipscomb TP, Schulman FY, Moffett D, et al. Morbilliviral disease in Atlantic bottlenose dolphins (Tursiops truncatus) from the 1987-1988 epizootic. J Wildl Dis. 1994;30(4):567-571.

47. Machado CAB. Antimicrobial Resistance of the Upper Respiratory Tract Commensal Microbiota in Bottlenose Dolphins (Tursiops truncatus), Under Human Care. Universidade de Lisboa; 2014.

48. McCullough SJ, McNeilly F, Allan GM, et al. Isolation and characterisation of a porpoise Morbillivirus. Arch Virol. 1991;118(3-4):247-252.

49. Moss WJ. Measles. Lancet. 2017;390(10111):2490-2502.

50. Quinn PJ, Markey BK, Leonard FC, et al. Veterinary Microbiology and Microbial Disease. John Wiley; 2011.

51. Renne R, McLaughlin R, Jenson A. Measles virus-associated endometritis, cervicitis, and abortion in a rhesus monkey. J Am Vet Med Assoc. 1973; 163(6):639-641.

52. Rodrigues TCS, Díaz-Delgado J, Catão-Dias JL, et al. Retrospective pathological survey of pulmonary disease in free-ranging Amazon river dolphin Inia geoffrensis and tucuxi Sotalia fluviatilis. Dis Aquat Organ. 2018;131(1):1-11.

53. Sacristán C, Catao-Dias JL, Ewbank AC, et al. Novel and highly sensitive SYBR(R) Green real-time pcr for poxvirus detection in odontocete cetaceans. J Virol Methods. 2018;259:45-49.

54. Sacristán C, Esperon F, Ewbank AC, et al. Novel herpesviruses in riverine and marine cetaceans from South America. Acta Trop. 2018;190:220-227.

55. Sacristán C, Esperon F, Marigo J, et al. Molecular identification and microscopic characterization of poxvirus in a Guiana dolphin and a common bottlenose dolphin, Brazil. Dis Aquat Organ. 2018;130(3):177-185.

56. Sánchez-Sarmiento AM, Carvalho VL, Díaz-Delgado J, et al. Molecular, serological, pathological, immunohistochemical and microbiological investigation of Brucella spp. in marine mammals of Brazil reveals new cetacean hosts. Transbound Emerg Dis. 2019;66(4):1674-1692.

57. Sánchez-Sarmiento AM, Carvalho VL, Sacristan C, et al. Brucellosis in a Clymene dolphin (Stenella clymene) stranded in Brazil. Transbound Emerg Dis. 2018;65(1):289-291.

58. Santos PS, Albuquerque GR, da Silva VM, et al. Seroprevalence of Toxoplasma gondii in free-living Amazon River dolphins (Inia geoffrensis) from central Amazon, Brazil. Vet Parasitol. 2011;183(1-2):171-173.

59. Santos-Neto EB. Influência de parâmetros biológicos (sexo, idade e maturidade sexual) nos padrões de acumulação de compostos organobromados do botocinza (Sotalia guianensis) da baía de Sepetiba, Rio de Janeiro, Brazil. Universidade do Estado do Rio de Janeiro, Brazil. University of Rio de Janeiro; 2017: 459.

60. Schaefer AM, Bossart GD, Harrington T, et al. Temporal changes in antibiotic resistance among bacteria isolated from common bottlenose dolphins (Tursiops truncatus) in the Indian River Lagoon, Florida, 2003-2015. Aquat Mamm. 2019; 45(5):533-542.

61. Schulman FY, Lipscomb TP, Moffett D, et al. Histologic, immunohistochemical, and polymerase chain reaction studies of bottlenose dolphins from the
1987-1988 United States Atlantic coast epizootic. Vet Pathol. 1997;34(4): 288-295.

62. Seade GCC, Cerqueira VD, Sierra E, et al. Herpesviral infection in a Guiana dolphin (Sotalia guianensis) from the northern coast of Brazil. J Vet Diagn Invest. 2017;29(6):877-879.

63. Sierra E, Fernández A, Suárez-Santana C, et al. Morbillivirus and pilot whale deaths, Canary Islands, Spain, 2015. Emerg Infect Dis. 2016;22(4):740-742.

64. Soares RM, Lopes EG, Keid LB, et al. Identification of Hammondia heydorni oocysts by a heminested-PCR (hnPCR-AP10) based on the H. heydorni RAPD fragment AP10. Vet Parasitol. 2011;175(1-2):168-172.

65. Stephens N, Duignan PJ, Wang J, et al. Cetacean morbillivirus in coastal IndoPacific bottlenose dolphins, Western Australia. Emerg Infect Dis. 2014;20(4): 666-670.

66. Stone BM, Blyde DJ, Saliki JT, et al. Fatal Cetacean morbillivirus infection in an Australian offshore bottlenose dolphin (Tursiops truncatus). Aust Vet J. 2011;89(11):452-457.

67. Taubenberger JK, Tsai MM, Atkin TJ, et al. Molecular genetic evidence of a novel Morbillivirus in a long-finned pilot whale (Globicephalus melas). Emerg Infect Dis. 2000;6(1):42-45.

68. Van Bressem MF, Duignan PJ, Banyard A, et al. Cetacean morbillivirus: current knowledge and future directions. Viruses. 2014;6(12):5145-5181.

69. Van Bressem MF, Raga JA, Di Guardo G, et al. Emerging infectious diseases in cetaceans worldwide and the possible role of environmental stressors. Dis Aquat Organ. 2009;86(2):143-157.

70. Van Bressem MF, Visser IK, Van de Bildt MW, et al. Morbillivirus infection in Mediterranean striped dolphins (Stenella coeruleoalba). Vet Rec. 1991;129(21): $471-472$.

71. VanDevanter DR, Warrener P, Bennett L, et al. Detection and analysis of diverse herpesviral species by consensus primer PCR. J Clin Microbiol. 1996;34(7):1666-1671.

72. Vandevelde M, Kristensen F, Kristensen B, et al. Immunological and pathological findings in demyelinating encephalitis associated with canine distemper virus infection. Acta Neuropathol. 1982;56(1):1-8.

73. West KL, Sanchez S, Rotstein D, et al. A Longman's beaked whale (Indopacetus pacificus) strands in Maui, Hawaii, with first case of Morbillivirus in the central Pacific. Mar Mamm Sci. 2013;29(4):767-776.

74. Williams ES, Barker IK. Infectious Diseases of Wild Mammals. John Wiley; 2008.

75. Wohlsein P, Saliki J. Rinderpest and peste des petits ruminants - the diseases: clinical signs and pathology. In: Rinderpest and Peste des Petits Ruminants. Elsevier; 2006:68-V.

76. Wohlsein P, Trautwein G, Harder TC, et al. Viral antigen distribution in organs of cattle experimentally infected with rinderpest virus. Vet Pathol. 1993;30(6): 544-554.

77. Yarim M, Kabakci N. The comparison of histopathological and immunohistochemical findings in natural canine distemper virus infection. Folia Vet. 2003; 47(2):86-90. 